Review

\title{
Biohydrogen Production from Lignocellulosic Biomass: Technology and Sustainability
}

\author{
Anoop Singh ${ }^{1, *}$, Surajbhan Sevda ${ }^{2}$, Ibrahim M. Abu Reesh ${ }^{2}$, Karolien Vanbroekhoven ${ }^{3}$, \\ Dheeraj Rathore ${ }^{4}$ and Deepak Pant ${ }^{3, *}$
}

Received: 16 June 2015 ; Accepted: 10 November 2015 ; Published: 17 November 2015

Academic Editor: Tariq Al-Shemmeri

1 Government of India, Ministry of Science and Technology, Department of Scientific and Industrial

Research (DSIR), Technology Bhawan, New Mehrauli Road, New Delhi 110016, India

2 Department of Chemical Engineering, Qatar University, Doha 2713, Qatar; sevdasuraj@gmail.com (S.S.); abureesh@qu.edu.qa (I.M.A.R.)

3 Separation and Conversion Technologies, Flemish Institute for Technological Research (VITO), Mol 2400, Belgium; karolien.vanbroekhoven@vito.be

4 School of Environment and Sustainable Development, Central University of Gujarat, Gandhinagar 382030, Gujarat, India; dheeraj.rathore@cug.ac.in

* Correspondence: apsinghenv@gmail.com (A.S.); deepak.pant@vito.be (D.P.); Tel.: +91-828-579-7386 (A.S.); +32-1433-6969 (D.P.); Fax: +32-1432-6586 (D.P.)

\begin{abstract}
Among the various renewable energy sources, biohydrogen is gaining a lot of traction as it has very high efficiency of conversion to usable power with less pollutant generation. The various technologies available for the production of biohydrogen from lignocellulosic biomass such as direct biophotolysis, indirect biophotolysis, photo, and dark fermentations have some drawbacks (e.g., low yield and slower production rate, etc.), which limits their practical application. Among these, metabolic engineering is presently the most promising for the production of biohydrogen as it overcomes most of the limitations in other technologies. Microbial electrolysis is another recent technology that is progressing very rapidly. However, it is the dark fermentation approach, followed by photo fermentation, which seem closer to commercialization. Biohydrogen production from lignocellulosic biomass is particularly suitable for relatively small and decentralized systems and it can be considered as an important sustainable and renewable energy source. The comprehensive life cycle assessment (LCA) of biohydrogen production from lignocellulosic biomass and its comparison with other biofuels can be a tool for policy decisions. In this paper, we discuss the various possible approaches for producing biohydrogen from lignocellulosic biomass which is an globally available abundant resource. The main technological challenges are discussed in detail, followed by potential solutions.
\end{abstract}

Keywords: biohydrogen; biofuels; lignocellulosic biomass; technology; sustainability; life cycle assessment

\section{Introduction}

Recent years have seen a rapid surge in research activities focusing intensely on alternative fuels in order to reduce the dependency on fossil fuels, mainly by providing local energetic resources. This is mainly due to two reasons, the first being that new fuels are needed to supplement and ultimately replace depleting oil reserves and secondly, fuels capable of low or nil $\mathrm{CO}_{2}$ emissions are urgently required to reduce the impact of global warming [1-7]. Hydrogen $\left(\mathrm{H}_{2}\right)$, which can be used in fuel cells mainly to operate machines, is a fascinating alternative, particularly because its combustion provides high amounts of energy and water is the only reaction product. Among all 
biofuels, $\mathrm{H}_{2}$ has the highest gravimetric energy density at $141 \mathrm{MJ} / \mathrm{kg}$. Despite this, its volumetric energy density, at only $12 \mathrm{MJ} / \mathrm{m}^{3}$ (at normal temperature and pressure) is low. This is an important aspect particularly in reference to transportation fuel. It is considered to be one of the cleanest energy carriers if produced using energy generated from renewable sources. In summary, $\mathrm{H}_{2}$ is interesting due to its potentially high efficiency of conversion to usable power, low generation of pollutants and high energy density [8]. Global $\mathrm{H}_{2}$ production today amounts to around 700 billion $\mathrm{Nm}^{3}$ and is based almost exclusively on fossil fuels [9]. However, for $\mathrm{H}_{2}$ to be accepted as a sustainable substitute for fossil fuels, it has to be produced from renewable feedstock other than fossil fuels [10].

Hydrogen has been suggested as the ideal fuel of the future. It is considered as one of the cleanest energy carriers to be generated from renewable sources [11]. It has a high energy yield $(122 \mathrm{~kJ} / \mathrm{g})$ which is 2.75 times greater than hydrocarbon fuels. It can be easily used in fuel cells for generation of electricity. Though not a primary energy source, it serves as a medium through which primary energy sources (such as $\mathrm{H}_{2}$ produced from nuclear power and/or solar energy) can be stored, transported and utilized to fulfill our energy needs. The major problem facing $\mathrm{H}_{2}$ as a fuel is its unavailability in Nature. $\mathrm{H}_{2}$ can be produced safely, is environmentally friendly when combusted, and versatile i.e., has many potential energy uses, including powering non-polluting vehicles, heating homes and offices, and fueling aircraft. Current $\mathrm{H}_{2}$ production technologies such as steam reforming of natural gas, thermal cracking or coal gasification are not environmentally friendly. Biological $\mathrm{H}_{2}$ production is a promising alternative. There are two methods to produce $\mathrm{H}_{2}$ from microorganisms. The first method uses photosynthetic microorganisms such as bacteria or algae (photofermentative processes) and the second method uses fermentative organisms (dark fermentation processes). Fermentative $\mathrm{H}_{2}$ production has the advantage of producing $\mathrm{H}_{2}$ under mild conditions with the additional benefit of allowing residual biomass valorization. The dark fermentation process is more attractive as it has the potential to use wastewater and organic wastes and has higher production rates compared to photofermentative processes. So far, few studies have used real wastewater for the production of $\mathrm{H}_{2}$ due to inhibition by both substrate and/or product in the fermentation process [12]. Studies on $\mathrm{bioH}_{2}$ production have been focused on photodecomposition of organic compounds by photosynthetic bacteria, dark fermentation from organic compounds with anaerobes and biophotolysis of water using algae and cyanobacteria [13-17].

Lignocellulosic biomass is the most abundant in Nature and it is present in hardwood, softwood, grasses, and agricultural residues. The global annual yields of lignocellulosic biomass residues were estimated to exceed 220 billion tons, equivalent to about 60-80 billion tons of crude oil [12]. Lignocellulosic feedstocks consist mainly of glucose and xylose and thus microbial strains that can effectively degrade glucose and xylose are important for development of renewable $\mathrm{H}_{2}$ production processes [18]. Direct conversion of lignocellulosic biomass to $\mathrm{H}_{2}$ needs pretreatment to hydrolyze the incorporated heterogeneous and crystalline structure $[19,20]$. The lignocellulosic biomass hence presents an attractive, low-cost feed stock for $\mathrm{H}_{2}$ production.

Aim of the Paper

In recent past, several reviews have appeared which have discussed the prospects and challenges of biomass-based $\mathrm{H}_{2}$ [21,22]. Earlier, Kraemer and Bagley gave a thorough description of the yield improvement approaches in fermentative $\mathrm{H}_{2}$ production [23]. Wang and Wan summarized the main factors influencing fermentative $\mathrm{H}_{2}$ production [24]. A special issue of the journal International Journal of Hydrogen Energy, recently dealt with "Biohydrogen: From Basic Concepts to Technology" [25]. Biohydrogen can be generated by adopting different technologies and different technologies can perform differently. Thus, the aim of this paper is to discuss specifically the technological aspect of biohydrogen production from lignocellulosic biomass and its sustainability on the basis of a life cycle assessment (LCA). 


\section{Feed Stock for Biohydrogen Production}

Glucose is the ideal substrate, but it is too costly at present. Many agricultural residues and food wastes are rich in carbohydrates that could serve as feedstock. Lignocellulosic biomass is another sustainable feedstock for $\mathrm{H}_{2}$ production [26]. The criteria for an ideal feedstock for sustainable $\mathrm{H}_{2}$ production, which include high carbohydrate content, minimum pre-treatment requirement, sustainable resources, low cost and sufficient concentration of carbohydrate for fermentative conversion, have been suggested by Bartacek [27]. The substrates usable for fermentative $\mathrm{H}_{2}$ production were further divided into four main groups, namely, pure substrates such as glucose; energy crops such as Miscanthus, solid wastes like food waste and industrial wastewaters such as wastewater from the pulp and paper industry.

A variety of substrates has been used as feedstock for $\mathrm{H}_{2}$ production. For example, the fermentation of household wastes under different temperature conditions has been well studied [28-30]. An increase in $\mathrm{H}_{2}$ yields as temperature increased to thermophilic regimes was reported.

Wastewaters and residual biomass with high carbohydrate content have also been demonstrated to be a suitable candidate for dark fermentation. This includes molasses [31,32] and cheese whey [33,34], which have been evaluated under continuous stirred tank reactor (CSTR) and immobilized system configurations. Besides, $\mathrm{H}_{2}$ production from soluble and particulate starch and cellulose [35,36], xylose [37], sugar beet [38], wastewater from a sugar beet refinery [39] and the bottom layer from a beer manufacturing plant [40] has also been demonstrated.

\section{Technology}

\subsection{Biohydrogen Production Systems}

The conventional methods for producing $\mathrm{H}_{2}$ gas include steam reforming of methane and hydrocarbons, non-catalytic partial oxidation of fossil fuels and autothermal reforming. However, most of these methods are energy intensive processes requiring high temperatures $\left(>850{ }^{\circ} \mathrm{C}\right)$. A general scheme of $\mathrm{H}_{2}$ production from renewable sources is shown in Figure 1. Biological methods of $\mathrm{H}_{2}$ production are preferable to chemical methods because of the possibility to use sunlight, $\mathrm{CO}_{2}$ and organic wastes as substrates for environmentally benign conversions, under moderate conditions.

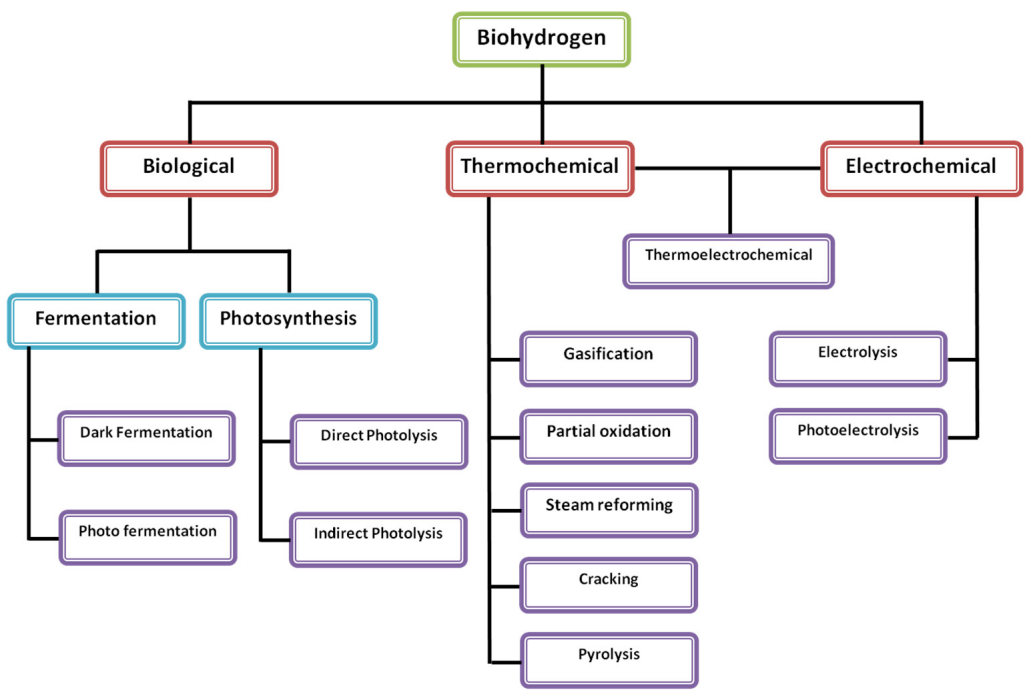

Figure 1. The main alternative methods of $\mathrm{H}_{2}$ production from energy sources.

The biological production of $\mathrm{H}_{2}$ involves light-dependent methods: direct and indirect biophotolysis, and photo fermentation. The other routes are light-independent methods, including 
the dark fermentation process and water-gas shift reaction of photoheterotrophic bacteria. This biologically produced $\mathrm{H}_{2}$, generally referred to as "biohydrogen", is characterized by low $\mathrm{H}_{2}$ yields which present a challenge for commercial applications.

\subsubsection{Dark/Anaerobic Fermentation}

Dark fermentation is one of the most common processes for bio- $\mathrm{H}_{2}$ production. Although only $15 \%-20 \%$ of the theoretical $\mathrm{H}_{2}$ potential of carbohydrates can be harvested, dark fermentation is considered as a promising process in a two phase anaerobic treatment system [23]. Also, since the $\mathrm{CO}_{2}$ produced in dark fermentation has already been fixed by the waste treated originally from the atmosphere, the emissions associated with global climate change are virtually zero [41]. Microbial species analysis of hydrogen-producing cultures (using anaerobic sludge as inoculum) shows the presence of Clostridium cellulosi, Clostridium acetobutylicum, Clostridium tyrobutyricum, Enterobacteriaceae and Streptococcus bovis [42] Fermentative $\mathrm{H}_{2}$ production usually proceeds from the anaerobic glycolytic breakdown of sugars. The theoretical complete oxidation of 1 mole of hexose to $\mathrm{CO}_{2}$ can produce 12 moles of $\mathrm{H}_{2}$. Nevertheless, the theoretical yield of $\mathrm{H}_{2}$ via acetic acid fermentation cannot be higher than 4 moles. Actual $\mathrm{H}_{2}$ yields are quite lower, typically ranging from 1.0 to 2.5 moles per mole of hexose consumed. Recently, Varanasi et al. reported production of $2.95 \mathrm{~mol}$ $\mathrm{H}_{2} / \mathrm{mol}$ hexose equivalent by thermophillic dark fermentation using cellubiose as substrate [43]. If butyric acid is produced as the major fermentation product instead of acetic acid, only 2 moles of $\mathrm{H}_{2}$ can be produced [44]. $\mathrm{H}_{2}$ yield is even lower when more reduced organic compounds such as lactic acid, propionic acid and ethanol are produced, because these metabolites represent end products of metabolic pathways that bypass the major $\mathrm{H}_{2}$-producing reaction [45]. Recently, it was concluded that to maximize net energy gain via dark fermentation, appropriate cultures capable of high- $\mathrm{H}_{2}$ yield have to be employed and the process has to be operated at near-ambient temperatures with the lowest feedstock concentration as possible [10]. In an experiment with Thermotoga neapolitana sparged with $\mathrm{N}_{2}$ and supplemented with $40 \mathrm{mM}$ sodium bicarbonate a 2.8 and $2.7 \mathrm{~mol} / \mathrm{mol}$ glucose yield of hydrogen with a lactic acid/acetic acid ratio of 0.26 was obtained, challenging the currently accepted dark fermentation model that predicts reduction of this gas when glucose is converted into organic products different from acetate [46]. Pradhan et al. reviewed the hydrogen production efficiency of a similar bacterium (Thermotoga neapolitana) with different feedstocks and found 1.9-3.5 $\mathrm{mol} \mathrm{H}_{2} / \mathrm{mol}$ hexose yields achievable with a range of feedstocks and variable substrate loads [47]. Byproducts of the reactions are acetic acid, lactic acid and ethanol.

\subsubsection{Photo Fermentation}

Photo fermentation is carried out by purple non-sulfur (PNS) photosynthetic bacteria which can grow as photoheterotrophs, photoautotrophs or chemoheterotrophs [48]. These bacteria produce $\mathrm{H}_{2}$ under photoheterotrophic conditions (light, anaerobiosis, organic electron donor) [49]. The advantages of this process over photolysis of water using green algae and cyanobacteria, are that oxygen does not inhibit the process and that these bacteria can be used in a wide variety of conditions (i.e., batch processes, continuous cultures, and immobilized systems) [50]. The hydrogenase and nitrogenase enzymes produced in photosynthesis by green algae and photosynthetic bacteria, respectively, play a crucial role in biohydrogen production. The main PNS bacteria that participate in $\mathrm{H}_{2}$ production are Rhodospirillum rubrum, Rhodopseudomonas palustris, Rhodobacter sphaeroides O.U 001, Rhodobacter sphaeroides RV, Rhodobacter sulfidophilus and Rhodobacter capsulatus. Kapdan et al. used three different pure strains of Rhodobacter sphaeroides (RV, NRLL and DSZM) in batch experiments to select the most suitable strain [51]. R. sphaeroides RV resulted in the highest cumulative hydrogen gas formation $(178 \mathrm{~mL})$, hydrogen yield $\left(1.23 \mathrm{~mol} \cdot \mathrm{H}_{2} \cdot \mathrm{mol}^{-1}\right.$ glucose $)$ and specific hydrogen production rate $\left(46 \mathrm{~mL} \cdot \mathrm{H}_{2} \cdot \mathrm{g}^{-1}\right.$ biomass $\left.\cdot \mathrm{h}^{-1}\right)$ at $5 \mathrm{~g} \cdot \mathrm{L}^{-1}$ initial total sugar concentration among the other pure cultures. Using Rhodobacter capsulatus JP91, Keskin and Hallenbeck compare the photofermentative biohydrogen yield of different feedstocks in a batch culture experiment [52]. 
Overall yield of biohydrogen was 10.5, 8 and $14.9 \mathrm{~mol} \mathrm{H}_{2} / \mathrm{mol}$ sucrose using beet molasses, black strap molasses and sucrose respectively. Optimization of process parameters such as availability of solar light, bioreactor configuration and proper $\mathrm{C} / \mathrm{N}$ ratio in substrate (synthetic and derived from waste products) still needs to be studied at higher scale.

\subsubsection{Combined Biotechnologies}

Combination of two or more of the abovementioned techniques have also been studied for improved $\mathrm{H}_{2}$ yields. Theoretically 12 moles of $\mathrm{H}_{2}$ per mole of glucose can be generated by combining dark fermentation with photo fermentation (using PNS bacteria) [48]. For instance, Nath et al. studied combined dark and photo fermentation using glucose as substrate [53]. The effluent from the dark process (containing unconverted metabolites, mainly acetic acid) underwent photo fermentation by Rhodobacter sphaeroides in a column photo-bioreactor demonstrating the feasibility of this combination to achieve higher yields of $\mathrm{H}_{2}$ by complete utilization of the chemical energy stored in the substrate. A sequential process using glucose as substrate and an immobilized system for the photo fermentation step evaluating key factors such as diluted ratio of dark fermentation effluent, ratio of dark and photo fermentation bacteria, light intensity, and light/dark cycle has also been studied [54]. During the combined process, maximum total $\mathrm{H}_{2}$ yield was 5.374 moles of $\mathrm{H}_{2} /$ moles of glucose. However, the sterilization step applied to the dark fermentation effluent may pose a constraint to a scale-up the process. The combined system can also be run in continuous mode and achieve more combined $\mathrm{H}_{2}$ yield [49]. These further combinations will reduce the overall cost of $\mathrm{H}_{2}$ production but more field studies are required to obtain an economical $\mathrm{H}_{2}$ production process.

\subsubsection{Bioelectrochemical Production}

Bioelectrochemical production of $\mathrm{H}_{2}$ is the latest technology using systems called microbial electrolysis cells (MEC). This is an emerging field where the oxidation of organic material is carried out by the bacteria present at the anode and results in formation of protons, $\mathrm{CO}_{2}$ and electrons (Figure 2). Protons migrate through a proton exchange membrane (PEM) to the cathode and the electrons are transported through the external circuit to the cathode [55]. By applying an external voltage of approximately $0.5-0.9 \mathrm{~V}$, these electrons combine at the cathode with protons producing $\mathrm{H}_{2}$ gas (Table 1$)$. The advantage here is the low energy consumption $(0.3-0.9 \mathrm{~V})$ necessary for microbial electrohydrogenesis to produce $\mathrm{H}_{2}$ in comparison to the theoretical minimum voltage of $1.23 \mathrm{~V}$ required for water electrolysis [56]. An overall scheme of $\mathrm{H}_{2}$ production from lignocellulosic biomass is shown in Figure 3. Figure 3 summarized the pathways for biohydrogen production by using lignocellulosic biomass, depending on the nature of feed (solid or liquid), pre-treatment methods were used and then followed by the dark fermentation.

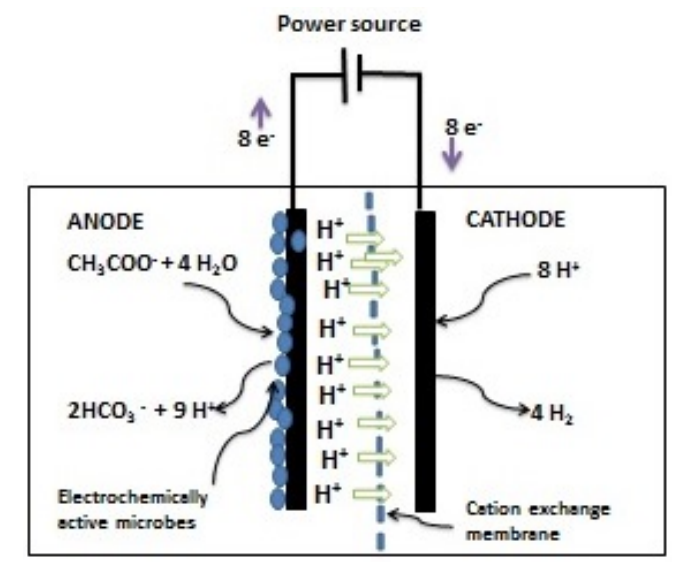

Figure 2. Schematic of hydrogen production in MEC (Adapted from [56]). 


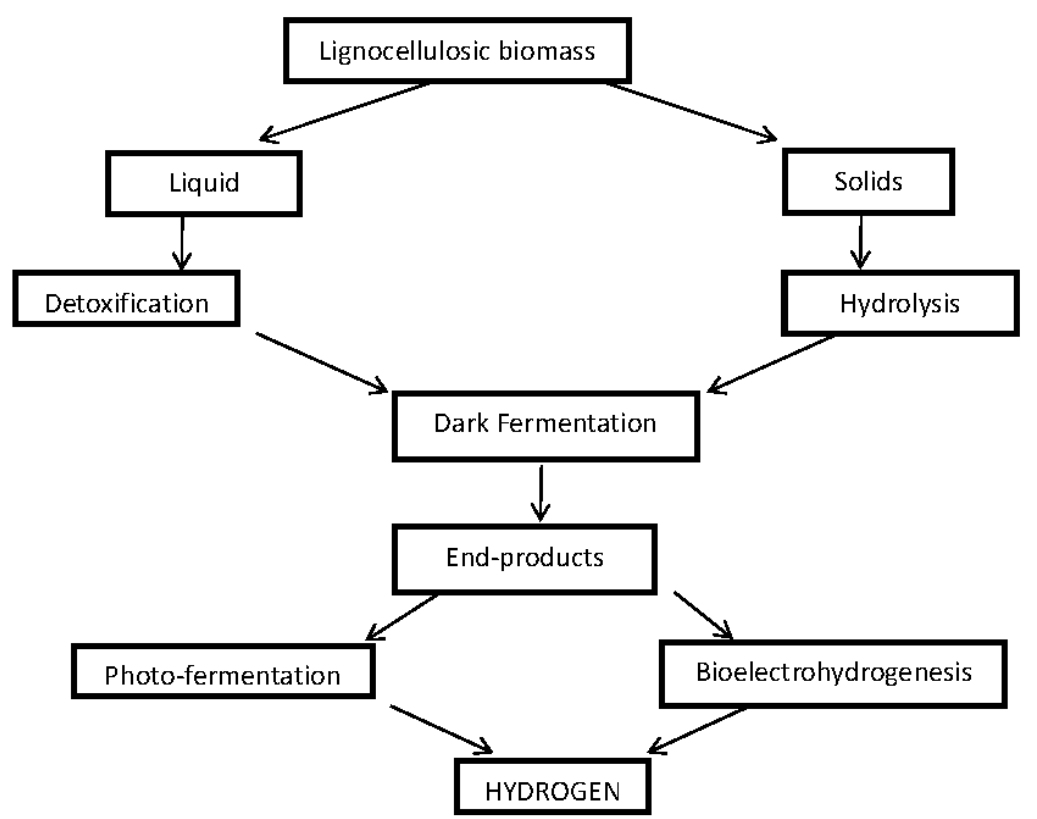

Figure 3. General scheme for biohydrogen production from lignocellulosic biomass (adapted from [12]).

Table 1. A comparison between the three major routes for biological hydrogen production (adapted from [57]).

\begin{tabular}{|c|c|c|c|}
\hline Production Routes & Main Reaction & $\begin{array}{c}\mathrm{H}_{2} \text { Production Rates } \\
(\mathrm{mmol} / \mathrm{h} \cdot \mathrm{L})\end{array}$ & Remark \\
\hline Direct photolysis & $\begin{array}{c}2 \mathrm{H}_{2} \mathrm{O}+\text { "light energy" } \\
\rightarrow 2 \mathrm{H}_{2}+\mathrm{O}_{2}\end{array}$ & 0.07 & $\begin{array}{l}\text { Similar to the processes } \\
\text { found in plants and } \\
\text { algal photosynthesis. }\end{array}$ \\
\hline Photo fermentation & $\begin{array}{c}\mathrm{C}_{6} \mathrm{H}_{12} \mathrm{O}_{6}+6 \mathrm{H}_{2} \mathrm{O}+ \\
\text { "light energy" } \rightarrow 12 \mathrm{H}_{2}+ \\
6 \mathrm{CO}_{2}, \Delta \mathrm{G}_{0}=+3.2 \mathrm{~kJ}\end{array}$ & $145-160$ & $\begin{array}{l}\text { Bacteria evolve } \\
\text { molecular } \mathrm{H}_{2} \text { catalyzed } \\
\text { by nitrogenase under } \\
\mathrm{N} \text {-deficient conditions } \\
\text { using light energy and } \\
\text { reduced compounds } \\
\text { (organic acids). }\end{array}$ \\
\hline Dark fermentation & $\begin{array}{c}\text { Pyruvate }+\mathrm{CoA} \rightarrow \\
\text { acetyl-CoA }+ \text { formate } \\
\text { OR Pyruvate }+ \text { CoA }+ \\
2 \mathrm{Fd}(\text { ox }) \rightarrow \text { Acetyl-CoA }+ \\
\mathrm{CO}_{2}+2 \mathrm{Fd}(\mathrm{red})\end{array}$ & 77 & $\begin{array}{l}\mathrm{H}_{2} \text { is produced by } \\
\text { anaerobic bacteria, } \\
\text { grown in the dark on } \\
\text { carbohydrate rich } \\
\text { substrate. }\end{array}$ \\
\hline
\end{tabular}

Table 2 shows the various substrates used for $\mathrm{H}_{2}$ production in different MEC volumes. The rate of $\mathrm{H}_{2}$ production differs with substrate due to their degradation pathways. To date MECs have shown $\mathrm{H}_{2}$ production from initial volumes ranging from $5 \mathrm{~mL}$ to $1000 \mathrm{~L}$ (pilot plant) reactors, which shows that MECs can be a better solution for producing $\mathrm{H}_{2}$ in the cathodic chamber while treating wastewater in the anodic chamber [58]. Still, there are many issues to be addressed for the long term real time application such as electrode and membrane stability for longer duration and reactor configuration design for higher volumes. Before scale up, mathematical models are required, which need to be validated first for the present lab scale studies and then on the basis of data obtained, higher volume MECs may be designed and validated. 
Table 2. Various substrates used in MEC for hydrogen production (adapted from [59]).

\begin{tabular}{|c|c|c|c|c|c|}
\hline Substrate & $\begin{array}{c}\text { Concentration } \\
(g / L)\end{array}$ & $\begin{array}{c}\text { Applied } \\
\text { Voltage (V) }\end{array}$ & $\begin{array}{l}\text { MEC Volume } \\
(\mathrm{mL})\end{array}$ & $\begin{array}{l}\text { Hydrogen Production } \\
\text { Rate }\left(\mathrm{m}^{3} \mathrm{H}_{2} / \mathrm{m}^{3} / \text { day }\right)\end{array}$ & Reference \\
\hline $\begin{array}{l}\text { A de-oiled refinery } \\
\text { wastewater }\end{array}$ & $04-1$ & 0.7 & 5 & $\begin{array}{l}79 \% \text { (Hydrogen } \\
\text { production based on } \\
\text { COD removal) }\end{array}$ & [60] \\
\hline Sodium Acetate & 1 & 0.6 & 18 & 2.0 & [61] \\
\hline Glucose & 2 & 0.6 & 26 & $0.25 \pm 0.03$ & [62] \\
\hline Glucose & 2 & 0.8 & 26 & $0.37 \pm 0.04$ & [62] \\
\hline $\begin{array}{l}\text { Fermentation } \\
\text { effluent }\end{array}$ & 1 & 0.6 & 26 & 1.41 & [63] \\
\hline Sodium Acetate & 1 & 0.6 & 28 & $1.99 \pm 0.02$ & [64] \\
\hline Sodium Acetate & 1 & 0.8 & 28 & $3.12 \pm 0.002$ & [64] \\
\hline Sodium Acetate & 1 & 0.5 & 28 & 1.7 & [65] \\
\hline Glucose & 1 & 0.5 & 28 & $0.83 \pm 0.18$ & [66] \\
\hline Glucose & 1 & 0.9 & 28 & $1.87 \pm 0.30$ & [66] \\
\hline Potato wastewater & $1.9-2.5(\mathrm{COD})$ & 0.9 & 28 & 0.74 & [67] \\
\hline Swine wastewater & $2(\mathrm{COD})$ & 0.5 & 28 & $0.9-1.0$ & [68] \\
\hline Sodium Acetate & 1 & 0.6 & 48 & 0.76 & [65] \\
\hline Sodium Acetate & 1 & 0.7 & 76 & - & [69] \\
\hline Sodium Acetate & 1 & 0.8 & 240 & $0.0231 \pm 0.003$ & [70] \\
\hline Sodium Acetate & 1 & 1 & 400 & 1.58 & [71] \\
\hline Sodium Acetate & 2 & 0.6 & 500 & 0.53 & [72] \\
\hline Winery wastewater & 8 & 0.9 & $1000 \mathrm{Lt}$ & $0.19 \pm 0.04$ & [58] \\
\hline Sodium Acetate & 1 & 0.5 & 6600 & 0.02 & [56] \\
\hline
\end{tabular}

\subsection{Microbiology of Biohydrogen Production}

Perera et al. evaluated three main routes for biological $\mathrm{H}_{2}$ production [10]. These are (1) direct photolysis, in which cyanobacteria decomposes water to generate hydrogen and oxygen in presence of light; (2) photo fermentation, where anoxygenic photoheterotrophic bacteria utilizes organic feedstock to produce $\mathrm{H}_{2}$ in presence of light and (3) dark fermentation, in which anaerobic heterotrophic bacteria utilizes organic feedstock without any light to produce $\mathrm{H}_{2}$. A comparison of these three main routes is shown in Table 1.

The microbiology and biochemistry of dark fermentative $\mathrm{H}_{2}$ production was discussed in detail by Hawkes et al. [42]. $\mathrm{H}_{2}$ production in Clostridia is due to the presence of hydrogenase enzymes. These transfer electrons from reduced ferredoxin or NADH to protons to regenerate the oxidized forms $\left(\mathrm{Fd}_{\mathrm{ox}}\right.$ and $\left.\mathrm{NAD}+\right)$ required so that glycolysis and oxidative decarboxylation of pyruvate can proceed to generate ATP.

Pure microbial cultures have mainly been used in lab-scale reactors for studying the effect of environmental and operational parameters on fermentation profiles and carbon metabolism. One of the successful tests using pure culture in a pilot-scale bioreactor using a non-sterilized feedstock employed Caldicellulosiruptor saccharolyticus [73]. However, most studies on $\mathrm{H}_{2}$ production on biowaste have been performed using mixed cultures under mesophilic conditions [74,75]. Only a few studies have focused on mixed thermophilic consortia [76,77]. It has been demonstrated that the extreme thermophile $C$. saccharolyticus can produce $\mathrm{H}_{2}$ from mono- and disaccharides [78]. Hexose is the predominant component in the cellulose hydrolysates. A highest $\mathrm{H}_{2}$ yield of approximately $83 \%$ of the theoretical value $\left(4 \mathrm{~mol} \cdot \mathrm{mol}^{-1}\right.$ hexose) has been reported using thermophilic anaerobic bacteria [78].

\subsection{Limiting Factors in Biohydrogen Production Systems}

The most challenging barrier of fermentative $\mathrm{H}_{2}$ production is its low $\mathrm{H}_{2}$ molar yield [26]. Thauer et al. predicted that 4 moles of $\mathrm{H}_{2}$ per mole of glucose is the biological maximum in Clostridial microbes if acetate is the only waste by-product [79]. In practice, even that figure is rarely achieved. A number of factors adversely affect and inhibit $\mathrm{H}_{2}$ fermentation [44]. $\mathrm{H}_{2}$ itself, when it reaches high concentrations not only makes its production thermodynamically unfavourable but also acts as an 
inhibitory agent as do other metabolic products, such as acetic acid and propionic acid $[17,80]$. Partial pressure of $\mathrm{H}_{2}$ is one of the most critical parameters in fermentative production of $\mathrm{H}_{2}$ as high $\mathrm{H}_{2}$ partial pressures make $\mathrm{H}_{2}$ production thermodynamically unfavourable. Removal of produced $\mathrm{H}_{2}$ from the liquid phase lowers the $\mathrm{H}_{2}$ partial pressure which in turn increases $\mathrm{H}_{2}$ yield [81]. Moreover, the $\mathrm{H}_{2}$ remaining in the system might be consumed by some bacteria [82]. Removal of dissolved $\mathrm{H}_{2}$ and reduction of $\mathrm{H}_{2}$ partial pressure can be achieved by nitrogen flushing, adsorption of $\mathrm{H}_{2}$ by metals and $\mathrm{H}_{2}$ stripping by boiling or by introduction of steam [83-85]. Low $\mathrm{H}_{2}$ partial pressure also needs to be maintained because hydrogenases (such as NiFe-hydrogenase) may re-oxidize the produced hydrogen into protons and electrons [86]. Gas sparging has proved to be an efficient method to maintain maximum hydrogen production even though it leads to biogas dilution and higher cost for hydrogen recovery [87]. Depending on the nature of the flushing gas, the flow rate and the reactor configuration, volumetric production of biogas up to $120 \%$ has been achieved $[85,88]$. Non-sparging techniques such as headspace modification under vacuum, high pressure or gas adsorption (reviewed in [87]), hydrogen-separating membranes [83] and using mechanical stirring [89,90], have also showed significant improvements in hydrogen yield. Argon has been often used to flush both oxygen and nitrogen and to keep a low $\mathrm{H}_{2}$ partial pressure in the reactors, but it increases production costs and hinders $\mathrm{H}_{2}$ purification [91]. Some researchers have reported reduced pressure and $\mathrm{CO}_{2}$ for flushing the headspace and maintaining low $\mathrm{H}_{2}$ partial pressure in dark fermentation [92,93], but the information on photofermentation is deficite. Montiel-Corona et al. suggested that flushing with Ar could be replaced with reduced pressure, which can be less expensive and practical for hydrogen recuperation [91]. Coupling the dark and photo fermentation showed an increased total hydrogen yield. One of the major drawbacks in coupling the dark and photo fermentation processes is the need of keeping apart the $\mathrm{H}_{2}$-producing microflora and the presence of $\mathrm{NH}_{4}{ }^{+}$, which may be naturally present in wastewater and may also be generated in the dark fermentation process when hydraulic retention time (HRT) is high enough to achieve protein degradation, especially when particulate substrates (as in the case of food wastes) are being considered, since HRT may be as high as 5 days [94].

In case of bioelectrochemical production of $\mathrm{H}_{2}$ in MEC, the main challenge is avoiding methane formation via methanogenesis [24], though researchers are now shifting more towards methane formation rather than $\mathrm{H}_{2}$ in these systems [95,96]. Another issue limiting the large-scale application of this technology is the use of precious metal catalyst such as platinum which is usually used on the cathode [97]. Though there have been efforts to use low cost materials such as stainless steel [98] and Ni-based electrodes [61], the results are much lesser from the targets.

\subsection{Role of Metabolic Engineering}

The application of genomic and molecular tools has made it possible to steer the metabolic pathways towards maximal $\mathrm{H}_{2}$ production and avoid waste and by-product accumulation. This is especially true when genetic engineering is conducted on cellulolytic microbes [26]. The main principles of genetic engineering include: (1) overexpression of cellulases, hemicellulases and lignases to maximize substrate availability, (2) elimination of $\mathrm{H}_{2}$-consuming hydrogenases and (3) overexpression of $\mathrm{H}_{2}$-producing hydrogenases [53]. Metabolic engineering modifications have been used to increase $\mathrm{H}_{2}$ production in fermentative systems [99]. These include over-expression of $\mathrm{H}_{2}$-evolving enzymes [100], the knockout of metabolic pathways that compete for reducing equivalents [81] and the introduction/over-expression of genes (cellulases, hemicellulases and lignases) to enhance carbohydrate availability to the cell [101]. Inactivation of the gene lactate dehydrogenase (ldhA) in E. coli by introducing mutations could lead to a modest increase $(20 \%-45 \%)$ in net hydrogen production (reviewed in [102]).

Ryu et al. combined several known approaches to construct a superior hydrogen-producing strain of the purple nonsulfur photosynthetic bacterium Rhodobacter sphaeroides HPCA* (mutant expressing NifA L62Q) [103]. In this strain maximum hydrogen levels are reached almost twice as 
fast as in wild type cells and final hydrogen levels are $\sim 39 \%$ higher than in the wild type as well. As increased number of genomes for $\mathrm{H}_{2}$ producing microorganisms are sequenced and compared and as more specific enzymes are functionally characterized, the distinctive metabolic strategies used and enzymological contexts through which $\mathrm{H}_{2}$ evolution is controlled in different organisms will become clearer. This will allow researchers to construct more effective strategies to modulate competing pathways, and help in the designing molecular engineering strategies leading to enhanced $\mathrm{H}_{2}$ evolution.

\section{Kinetic Models for Hydrogen Production by Fermentation}

Different factors such as substrate and inhibitor concentrations, temperature, $\mathrm{pH}$ and reactor type affect $\mathrm{H}_{2}$ production by fermentation. Modeling of the $\mathrm{H}_{2}$ production is very important to improve, analyze and predict $\mathrm{H}_{2}$ production during fermentation. Mathematical models include the kinetic of cell growth and product(s) formation, substrate utilization and inhibition. In addition some models are developed to describe the effect of $\mathrm{pH}$, temperature and dilution rate on $\mathrm{H}_{2}$ production. The obtained model kinetic constants can be used in the design, operation and optimization of the fermentative $\mathrm{H}_{2}$ production process. Different kinetic models have been proposed to describe growth of $\mathrm{H}_{2}$ producing bacteria, substrate degradation and $\mathrm{H}_{2}$ production. $\mathrm{H}_{2}$ production is reported as growth associated product.

Monod (or Michaelis-Menten equation) (Equation (1)) which is an unstructured, non-segregated model of microbial growth, fits a wide range of data. The kinetic constants of this equation, $K_{S}$ and $\mu_{\max }$, can be obtained by linear regression. Wang and Wan reported on previous studies using a Monod model to describe $\mathrm{H}_{2}$ production with time in bio- $\mathrm{H}_{2}$ fermentation [104]:

$$
\mu=\frac{1}{X} \frac{d X}{d t}=\mu_{m} \frac{S}{K_{s}+S}
$$

where $\mu$ is the specific growth rate, $X$ is the biomass concentration, $S$ is the substrate concentration, $K_{s}$ is the saturation constant, $\mu_{m}$ is the maximum specific growth rate.

Recently, the logistic model (Equation (2)) became the most popular in describing cell growth. This equation has a sigmoidal shape that includes the lag phase, exponential and stationary phase of the batch growth:

$$
\mu=\frac{1}{X} \frac{d X}{d t}=\mu_{m}\left(1-\frac{X}{X_{m}}\right)
$$

where $X_{m}$ is the maximum biomass concentration.

At high substrate concentration, the cell growth is inhibited and production of $\mathrm{H}_{2}$ is reduced. Different substrate inhibition models have been proposed. The Haldane-Andrew model (Equation (3)) is widely used to describe the substrate dependence of the specific growth rate of $\mathrm{H}_{2}$ fermentations. Wang and Wan have reported that previous studies used an Andrews model to describe $\mathrm{H}_{2}$ production with time [104]. Other substrate inhibition models are used in the literature such as modified Han-Levenspiel model (Equation (4)):

$$
\mu=\frac{1}{X} \frac{d X}{d t}=\mu_{m} \frac{S}{K_{S}+S+\frac{S^{2}}{K_{i}}}
$$

where $K_{i}$ is the inhibition constant.

The presence of other inhibitors such as salts and the product cause reduction of $\mathrm{H}_{2}$ production. Some models have been proposed to describe the effect of inhibitors such as the modified Han-Levenspiel model (Equation (4)):

$$
\mu=\frac{1}{X} \frac{d X}{d t}=\mu_{m}\left(1-\frac{C}{C_{m}}\right)
$$


where $C$ is the inhibitor concentration, $C_{m}$ is the maximum inhibitor concentration or the concentration of inhibitor above which there is no biomass growth

The modified Gompertz model (Equation (5)) is widely used to describe the progress of cumulative $\mathrm{H}_{2}$ production in batch fermentations [104]:

$$
H_{t}=H_{\max } \exp \left\{-\exp \left[\frac{R_{\max } \times e}{H_{\max }}(\lambda-t)+1\right]\right\}
$$

where $H_{t}$ is the cumulative volume of $\mathrm{H}_{2}$ produced at any time $(\mathrm{mL}), H_{\max }$ is the gas production potential $(\mathrm{mL}), R_{\max }$ is the maximum gas production rate $(\mathrm{mL} / \mathrm{h}), \lambda$ is the lag time $(\mathrm{h}) . t$ is the incubation time (h)

The Luedeking-Piret model (Equation (6)) has been widely used to describe the relation between cell growth rate and $\mathrm{H}_{2}$ production:

$$
\frac{d P}{d t}=Y_{P / X} \frac{d X}{d t}+\beta X
$$

where $P$ is the product, $Y_{P / X}$ is the growth associated yield coefficient; $\beta$ is the non-growth associated product yield coefficient.

Wang and Wan reported that previous studies used the Luedeking-Piret model to relate cell growth rate and $\mathrm{H}_{2}$ production rate [104]. The effect of temperature on the fermentative $\mathrm{H}_{2}$ production has been widely described using the Arrhenius model, while the effect of $\mathrm{pH}$ on the substrate consumption rate is described by an Andrew model using the concentration of $\mathrm{H}^{+}$as the limiting substrate concentration. According to this model, the rate of substrate consumption passes through maximum with increasing $\mathrm{H}^{+}$concentration.

\section{Sustainability and Life Cycle Assessment}

The concept of sustainable development is an attempt to combine growing concerns about a range of environmental issues with socio-economic issues and implies smooth transition to more effective technologies from a point view of an environmental impact and energy efficiency $[105,106]$. $\mathrm{H}_{2}$ can be considered one of the pillars of a future sustainable energy system [107]. $\mathrm{H}_{2}$ production could be a possible avenue for the large-scale sustainable generation of $\mathrm{H}_{2}$ needed to fuel a future $\mathrm{H}_{2}$ economy [106]. Despite its many obvious advantages, there remains a problem with storage and transportation. Pressurized $\mathrm{H}_{2}$ gas occupies a great deal of volume compared with other fuels. For example, gasoline that with equal energy content, needs about 30 times less volume at 100 bar gas pressure. Due to its high explosivity there are also obvious safety concerns with the use of pressurized or liquefied $\mathrm{H}_{2}$ in vehicles as well as additional energy use for pressurizing or liquefaction. Furthermore, the overall energy balance of using $\mathrm{H}_{2}$ as vehicle fuel does indeed seem to be less beneficial than gasoline, but being the only non-carbon fuel it may still make sense to produce $\mathrm{H}_{2}$ from waste streams if some of the obstacles can be solved and it can be used effectively for energy production to feed into grid or to use in stationary requirements, e.g., industries, etc.

Though this paper is focused on bio- $\mathrm{H}_{2}$ production from lignocellulosic biomass, it is important to compare it to other production methods using various substrates. Such a comparison has been made in Table 3 by presenting the various $\mathrm{H}_{2}$ production systems, which show different $\mathrm{H}_{2}$ yields from different feedstocks by adopting different production systems. Therefore, life cycle assessment (LCA) could be a tool to scrutinize the best $\mathrm{H}_{2}$ production system for a particular feedstock in terms of environmental impact and indirect natural resource costs towards different services and commodities [108]. LCA allows the possibility of comparing different $\mathrm{H}_{2}$ production approaches and identifying the environmental "hot spot" of the whole process, which helps in development of a sustainable $\mathrm{H}_{2}$ production process $[106,109]$. Investigations of the environmental benefits and impacts from a life cycle perspective are scarce. Only a few LCA-studies have been performed 
specifically on $\mathrm{H}_{2}$ production. The feedstocks investigated so far are steamed potato peel, wheat straw and sweet sorghum stalks [110-112].

Table 3. Comparison of different biohydrogen production systems.

\begin{tabular}{|c|c|c|c|}
\hline Reactor & Feed Stock & Maximum $\mathrm{H}_{2}$ Yield & Reference \\
\hline \multicolumn{4}{|c|}{ Fermentation } \\
\hline \multicolumn{4}{|c|}{ Dark fermentation } \\
\hline CSTR & Starch & $\begin{array}{c}0.52 \mathrm{~L} / \mathrm{h} / \mathrm{L} \text { and } 13.2 \mathrm{mmol} \mathrm{H}_{2} / \mathrm{g} \\
\text { total sugar }\end{array}$ & [113] \\
\hline Batch & Glycerol & $0.41 \mathrm{~mol} \mathrm{H}_{2} / \mathrm{mol}$ glycerol & {$[114]$} \\
\hline FBR & Sucrose & $4.26 \mathrm{~mol} \mathrm{H}_{2} / \mathrm{mol}$ sucrose & [115] \\
\hline Batch & Food waste & $593 \mathrm{~mL} \mathrm{H}_{2} / \mathrm{g}$ carbohydrate & [116] \\
\hline Fed-batch & Swine manure & $18.7 \times 10^{-3} \mathrm{~g} \mathrm{H}_{2}$ per g TVS & [117] \\
\hline Batch & Sucrose & $4.3 \mathrm{~mol} \mathrm{H}_{2} / \mathrm{mol}$ sucrose & [118] \\
\hline Batch & Fructose, sorbitol, glucose & $1.27,1.46$ and $1.51 \mathrm{~mol} \mathrm{H}_{2}$ /substrate & [119] \\
\hline Fed-batch & Starch, glucose & $\begin{array}{c}465 \mathrm{~mL} \mathrm{H}_{2} / \mathrm{g} \text { starch, } \\
3.1 \mathrm{~mol} \mathrm{H}_{2} / \mathrm{mol} \text { glucose }\end{array}$ & [120] \\
\hline Batch & Food waste & $\begin{array}{c}39.14 \mathrm{~mL} \mathrm{H}_{2} / \mathrm{g} \text { food waste } \\
\left(219.91 \mathrm{~mL} \mathrm{H}_{2} / \mathrm{VS}_{\text {added }}\right)\end{array}$ & [121] \\
\hline Batch & Crude Glycerol & $\begin{array}{c}64.24 \mathrm{mmol} \mathrm{H}_{2} / \mathrm{L} \text { and } \\
5.74 \mathrm{mmol} \mathrm{H}_{2} / \mathrm{g} \mathrm{COD} \text { consumed }\end{array}$ & [122] \\
\hline Batch & Distillery wastewaters & $1 \mathrm{~L} \mathrm{H}_{2} / \mathrm{L}$ medium & [123] \\
\hline Batch & Cheese whey & $94.2 \mathrm{~L} \mathrm{H}_{2} / \mathrm{kgvs}$ & {$[124]$} \\
\hline Batch & $\begin{array}{c}\text { Water hyacinth } \\
\text { (leaves and stems) }\end{array}$ & $\begin{array}{c}76.7 \mathrm{~mL} \mathrm{H}_{2} / \mathrm{g} \text { TVS was obtained at } \\
20 \mathrm{~g} / \mathrm{L} \text { of water hyacinth }\end{array}$ & [125] \\
\hline Batch & $\begin{array}{l}\text { waste ground wheat } \\
\text { solution }\end{array}$ & $\mathrm{SHPR}=25.7 \mathrm{~mL} \mathrm{H}_{2} / \mathrm{g}$ cells $/ \mathrm{h}$ & [126] \\
\hline \multicolumn{4}{|c|}{ Photo fermentation } \\
\hline CSTR & Sucrose & $5.81 \mathrm{~mol} \mathrm{H}_{2} / \mathrm{mol}$ hexose & [127] \\
\hline Fed-batch operation & Wheat starch & $201 \mathrm{~mL} \mathrm{H}_{2} \mathrm{~g} / \mathrm{L}$ starch & [128] \\
\hline Batch & Molasses & $0.50 \mathrm{mmol} \mathrm{H}_{2} / \mathrm{L}_{\mathrm{c}} \mathrm{h}$ & [129] \\
\hline Batch & Beet molasses & $10.5 \mathrm{~mol} \mathrm{H}_{2} / \mathrm{mol}$ sucrose & [52] \\
\hline Batch & Black strap & $8 \mathrm{~mol} \mathrm{H}_{2} / \mathrm{mol}$ sucrose & [52] \\
\hline Batch & Sucrose & $14 \mathrm{~mol} \mathrm{H}_{2} / \mathrm{mol}$ sucrose & [52] \\
\hline Batch & Ground wheat starch & $\begin{array}{c}46 \mathrm{~mL} \mathrm{H}_{2} / \mathrm{g} \text { biomass } / \mathrm{h}, 1.23 \mathrm{~mol} \\
\mathrm{H}_{2} / \mathrm{mol} \text { glucose }\end{array}$ & [51] \\
\hline Batch & $\begin{array}{c}\text { lignocellulose-derived } \\
\text { organic acids }\end{array}$ & $\begin{array}{l}7 \mathrm{~mL} \mathrm{H}_{2} / \mathrm{mL} \text { of the } \\
\text { fermentation effluent }\end{array}$ & [130] \\
\hline \multicolumn{4}{|c|}{ Photosynthesis } \\
\hline \multicolumn{4}{|c|}{ Direct Photolysis } \\
\hline Batch & Lactate & $\begin{array}{c}0.07 \mathrm{mmol} \mathrm{H}(1 \times \mathrm{h}) \text { or } \\
54 \mathrm{~mL} / \mathrm{h} \cdot \mathrm{g} \text { dry weight }\end{array}$ & [131] \\
\hline \multicolumn{4}{|c|}{ Indirect Photolysis } \\
\hline Batch & arabinose and xylose & $\begin{array}{c}14.55 \mathrm{mmol} / \mathrm{g} \text { (arabinose); } \\
13.73 \mathrm{mmol} / \mathrm{g} \text { (xylose) }\end{array}$ & [132] \\
\hline \multicolumn{4}{|c|}{ Thermochemical } \\
\hline \multicolumn{4}{|c|}{ Gasification } \\
\hline $\begin{array}{c}\text { Continuous } \\
\text { supercritical water } \\
\text { gasification }\end{array}$ & glucose & $10.5-11.2 \mathrm{~mol} / \mathrm{mol}$ glucose & [133] \\
\hline \multicolumn{4}{|c|}{ Partial Oxidation } \\
\hline Batch & municipal sludge & Not reported the amount & [134] \\
\hline \multicolumn{4}{|c|}{ Steam reforming } \\
\hline $\begin{array}{l}\text { molten carbonate fuel } \\
\text { cell (MCFC) system }\end{array}$ & ethanol & $5 \mathrm{~mol} \mathrm{H}_{2} / \mathrm{mol}$ fed ethanol & [135] \\
\hline \multicolumn{4}{|c|}{ Cracking } \\
\hline $\begin{array}{l}\text { fixed-bed quartz } \\
\text { micro reactor }\end{array}$ & Methane & $500 \mu \mathrm{moles} / \mathrm{min}$ & [136] \\
\hline \multicolumn{4}{|c|}{$\begin{array}{c}\text { Pyrolysis } \\
\end{array}$} \\
\hline $\begin{array}{l}\text { stainless steel tank } \\
\text { reactor }\end{array}$ & $\begin{array}{c}\text { Biomass (redwood } \\
\text { sawdust; cole stalk and rice } \\
\text { husk) feed }\end{array}$ & $\begin{array}{c}65.39 \mathrm{~g} / \mathrm{Kg} \text { biomass for redwood } \\
\text { sawdust; } 40.0 \mathrm{~g} / \mathrm{Kg} \text { biomass for cole } \\
\text { stalk and rice husk }\end{array}$ & [137] \\
\hline \multicolumn{4}{|c|}{ Thermoelectrochemical } \\
\hline $\begin{array}{l}\text { membrane electrode } \\
\text { assembly }\end{array}$ & sulfur dioxide & $\begin{array}{c}0.4 \mathrm{~A} / \mathrm{cm}^{2} \text { at } 0.835 \mathrm{~V}\left(\mathrm{H}_{2} \text { production }\right. \\
\text { rate did not reported) }\end{array}$ & [138] \\
\hline $\begin{array}{l}\text { membrane electrode } \\
\text { assembly }\end{array}$ & $\begin{array}{l}\text { anhydrous hydrogen } \\
\text { bromide }\end{array}$ & $\begin{array}{l}2.0 \mathrm{~A} / \mathrm{cm}^{2} \text { at } 1.91 \mathrm{~V}\left(\mathrm{H}_{2} \text { production }\right. \\
\text { rate did not reported })\end{array}$ & [138] \\
\hline
\end{tabular}


Table 3. Cont.

\begin{tabular}{|c|c|c|c|}
\hline Reactor & Feed Stock & Maximum $\mathrm{H}_{2}$ Yield & Reference \\
\hline \multicolumn{4}{|c|}{ Electrochemical } \\
\hline \multicolumn{4}{|c|}{ Electrolysis } \\
\hline $\begin{array}{c}\text { The } \mathrm{BiO} x-\mathrm{TiO}_{2} \\
\text { electrode and } \\
\text { stainless steel (SS, } \\
\text { Hastelloy C-22) were } \\
\text { used as an anode and } \\
\text { a cathode in the } \\
\text { electrochemical } \\
\text { system, respectively }\end{array}$ & arsenite $(\mathrm{As}(\mathrm{III}))$ & $9.4 \mu \mathrm{moles} / \mathrm{min}$ & [139] \\
\hline \multicolumn{4}{|c|}{ Photoelectrolysis } \\
\hline $\begin{array}{l}\text { The } \mathrm{TiO}_{2}(\mathrm{~ns}) \text { was } \\
\text { prepared in the form } \\
\text { of a sol-gel }\end{array}$ & $\begin{array}{l}\text { photoelectrode system } \\
\mathrm{TiO}_{2}(\mathrm{~ns})-\mathrm{VO}_{2}\end{array}$ & $\begin{array}{c}6 \mathrm{~L} \cdot \mathrm{h}^{-1} \cdot \mathrm{m}^{-2} \text { for the } \mathrm{TiO}_{2}(\mathrm{~ns}) ; 13.0 \\
\mathrm{~L} \cdot \mathrm{h}^{-1} \cdot \mathrm{m}^{-2} \text { for the } \mathrm{TiO}_{2}(\mathrm{~ns})-\mathrm{VO}_{2} \\
\text { photoelectrode }\end{array}$ & [140] \\
\hline
\end{tabular}

In connection with a European research study, HYVOLUTION, the life cycle environmental impacts of pilot production of $\mathrm{H}_{2}$ through thermophilic fermentation, and photo fermentation of potato peel was compared to production of $\mathrm{H}_{2}$ from natural gas through steam methane reforming (SMR) [112]. It was demonstrated that the bio- $\mathrm{H}_{2}$ production had approximately 5.7 times higher environmental impacts (negative impacts on the environment) than a centralized SMR. The processes involved in steam (pretreatment), phosphate buffer (used in photo fermentation) and potassium hydroxide (used in thermophilic fermentation), were the main causes of the environmental impact (98.3\%). Recirculation of the sewage reduces the environmental impacts considerably to having only approximately two times more environmental impact than SMR. If instead biomethane were produced for use in the SMR the environmental impact would be reduced to less than $1 / 3$ of the traditional SMR [112]. On the other hand alternative use of the peel would be as animal feed and Djomo et al. showed that the production of bio- $\mathrm{H}_{2}$ is more beneficial than the use as animal feed by a factor of 2-3 [110]. In a more recent study Djomo and Blumberga investigated potential differences in environmental performance between the three different feedstocks [111]. They performed a "well-to-tank" study i.e., the system boundary is at supplying $\mathrm{H}_{2}$ to road vehicles meaning that the combustion and transportation of $\mathrm{H}_{2}$ in the vehicles, was not included. Further, the production of feedstock was excluded as they are considered wastes. Their conclusion is in contrast to the earlier study they find that $\mathrm{H}_{2}$ produced from any of the feedstock reduced GHG-emissions by approximately $55 \%$ compared to SMR and a few percent less for gasoline. When the subsequent use of the remains from the $\mathrm{H}_{2}$ production were considered as animal feed, an environmental benefit could be observed. The energy ratio calculated was $1.08-1.17$, i.e., the energy gain is between 8 and $17 \%$. Though steamed potato peel was slightly better, no significant environmental differences were observed between the feedstocks [111]. The results compare well with those of Manish and Banerjee who investigated the energy balance of $\mathrm{H}_{2}$ and found an energy ratio of 3.1 (excluding the gas treatment and the compressing) [57].

The conclusion from these studies from an environmental view point is that the production of $\mathrm{H}_{2}$ for renewable energy production from potato peel could be preferred to using SMR or as direct animal feed due to the lesser environmental impacts. The LCA studies can further be used for identification of the main environmental improvements in the technology development (e.g., recirculation of the sewage and reuse of the remains for animal feed). The LCA of $\mathrm{H}_{2}$ is very important before taking them into consideration for commercial scale production and policy decisions on $\mathrm{H}_{2}$ promotion.

\section{Future Directions and Perspectives}

One option proposed to lower feedstock costs is to identify microbes that can directly utilize hemicellulose and cellulose [26]. This would eliminate the need for cellulase enzymes and simplify biomass pretreatment. As cellulose is the most abundant biopolymer in the world [141], its 
bioconversion provides a viable approach to produce renewable $\mathrm{H}_{2}$ from organic matter. The combined dark fermentation coupling with photo fermentation, or dark fermentation coupling with bioelectrohydrogenesis is a promising $\mathrm{H}_{2}$ production process from lignocellulosic biomass if the technological barriers can be overcome [12]. Overall, to develop a mature $\mathrm{H}_{2}$ production technology, bioconversion performance from lignocellulosic biomass need to be further improved in terms of production rates, cost-effectiveness, and system scale-up. Based on the limited number of LCA studies done on $\mathrm{H}_{2}$ production, it can be assumed that the bioconversion of lignocelluloses-to- $\mathrm{H}_{2}$ on industrial scale is a feasible option to produce $\mathrm{H}_{2}$ via biotechnology. However, more in-depth studies need to be carried out to confirm this.

\section{Conclusions}

Although considerable progress has been made on $\mathrm{H}_{2}$ production from lignocellulosic biomass, several challenges remain for its commercial application. Among the various techniques available for $\mathrm{H}_{2}$ production from lignocellulosic biomass, dark fermentation seems to have an edge over the others and is the closest to commercialization. Photo fermentation is the next best option, though it has to overcome the problems associated with reactor design and operation. Bioelectrochemical $\mathrm{H}_{2}$ production is still in its infancy and needs much more research and development. The kinetic models for $\mathrm{H}_{2}$ production provide insights on substrate utilization and factors limiting higher yields. The models will help in scale up studies for validating the proposed data and later on with the experimental data. The few environmental assessment studies performed from a LCA perspective show that $\mathrm{H}_{2}$ production from lignocellulosic biomass also may be preferable to other renewable energy production pathways. Such studies can furthermore help identifying technological improvement options. The results of LCA studies could also help policy makers in taking decision on policies related to promotion of renewable energy.

Author Contributions: Anoop Singh and Deepak Pant originated the manuscript idea, created the outline, wrote parts of the manuscript and did the final editing. Surajbhan Sevda and Ibrahim M. Abu Reesh wrote about the modelling aspect and prepared the final revised draft. Karolien Vanbroekhoven and Dheeraj Rathore contributed to different sections of the manuscript mainly microbial electrolysis and sustainability.

Conflicts of Interest: The authors declare no conflict of interest.

\section{References}

1. Prasad, S.; Singh, A.; Joshi, H.C. Ethanol as an alternative fuel from agricultural, industrial and urban residues. Resour. Conserv. Recycl. 2007, 50, 1-39. [CrossRef]

2. Prasad, S.; Singh, A.; Joshi, H.C. Ethanol production from sweet sorghum syrup for utilization as automotive fuel in India. Energy Fuels 2007, 21, 2415-2420. [CrossRef]

3. Pant, D.; Van Bogaert, G.; Diels, L.; Vanbroekhoven, K. A review of the substrates used in microbial fuel cells (MFCs) for sustainable energy production. Bioresour. Technol. 2010, 101, 1533-1543. [CrossRef] [PubMed]

4. Pant, D.; Singh, A.; van Bogaert, G.; Gallego, Y.A.; Diels, L.; Vanbroekhoven, K. An introduction to the life cycle assessment (LCA) of bioelectrochemical systems (BES) for sustainable energy and product generation: Relevance and key aspects. Renew. Sustain. Energy Rev. 2011, 15, 1305-1313. [CrossRef]

5. Singh, A.; Smyth, B.M.; Murphy, J.D. A biofuel strategy for Ireland with an emphasis on production of biomethane and minimization of land-take. Renew. Sustain. Energy Rev. 2010, 14, 277-288. [CrossRef]

6. Singh, A.; Pant, D.; Korres, N.E.; Nizami, A.; Prasad, S.; Murphy, J.D. Key issues in life cycle assessment of ethanol production from lignocellulosic biomass: Challenges and perspectives. Bioresour. Technol. 2010, 101, 5003-5012. [CrossRef] [PubMed]

7. Singh, A.; Nigam, P.S.; Murphy, J.D. Renewable fuels from algae: An answer to debatable land based fuels. Bioresour. Technol. 2011, 102, 10-16. [CrossRef] [PubMed]

8. Hallenbeck, P.C.; Ghosh, D. Advances in fermentative biohydrogen production: The way forward? Trends Biotechnol. 2009, 27, 287-297. [CrossRef] [PubMed]

9. Ball, M.; Wietschel, M. The future of hydrogen-Opportunities and challenges. Int. J. Hydrog. Energy 2009, 34, 615-627. [CrossRef] 
10. Perera, K.R.J.; Ketheesan, B.; Gadhamshetty, V.; Nirmalakhandan, N. Fermentative biohydrogen production: Evaluation of net energy gain. Int. J. Hydrog. Energy 2010, 35, 12224-12233. [CrossRef]

11. Kovacs, K.; Maroti, G.; Rakhely, G. A novel approach for biohydrogen production. Int. J. Hydrog. Energy 2006, 31, 1460-1468. [CrossRef]

12. Ren, N.; Wang, A.; Cao, G.; Xu, J.; Gao, L. Bioconversion of lignocellulosic biomass to hydrogen: Potential and challenges. Biotechnol. Adv. 2009, 27, 1051-1060. [CrossRef] [PubMed]

13. Kumar, N.; Das, D. Enhancement of hydrogen production by Enterobacter cloacae IIT-BT 08. Process Biochem. 2000, 35, 589-593. [CrossRef]

14. Chen, C.C.; Lin, C.Y.; Chang, J.S. Kinetics of hydrogen production with continuous anaerobic cultures utilizing sucrose as the limiting substrate. Appl. Microbiol. Biotechnol. 2001, 57, 56-64. [PubMed]

15. Ginkel, S.V.; Sung, S.; Lay, J.J. Biohydrogen production as a function of $\mathrm{pH}$ and substrate concentration. Environ. Sci. Technol. 2001, 35, 4726-4730. [CrossRef] [PubMed]

16. Xing, D.; Ren, N.; Li, Q.; Lin, M.; Wang, A.; Zhao, L. Ethanoligenens harbinense gen. nov., sp. nov., isolated from molasses wastewater. Int. J. Syst. Evolut. Microbiol. 2006, 56, 755-760. [CrossRef] [PubMed]

17. Wang, L.; Zhou, Q.; Li, F. Avoiding propionic acid accumulation in the anaerobic process for biohydrogen production. Biomass Bioenergy 2006, 30, 177-182. [CrossRef]

18. Ren, N.; Cao, G.; Guo, W.; Wang, A.; Zhu, Y.; Liu, B.; Xu, J. Biological hydrogen production from corn stover by moderately thermophile Thermoanaerobacterium thermosaccharolyticum W16. Int. J. Hydrog. Energy 2010, 35, 2708-2712. [CrossRef]

19. De Vrije, T.; de Haas, G.; Tan, G.B.; Keijsers, E.R.; Claassen, P.A.M. Pretreatment of Miscanthus for hydrogen production by Thermotoga elfii. Int. J. Hydrog. Energy 2002, 27, 1381-1390. [CrossRef]

20. Ntaikou, I.; Gavala, H.N.; Kornaros, M.; Lyberatos, G. Hydrogen production from sugars and sweet sorghum biomass using Ruminococcus albus. Int. J. Hydrog. Energy 2008, 33, 1153-1163. [CrossRef]

21. Kapdan, I.K.; Kargi, F. Bio-hydrogen production from waste materials. Enzym. Microb. Technol. 2006, 38, 569-582. [CrossRef]

22. Kalinci, Y.; Hepbasli, A.; Dincer, I. Biomass-based hydrogen production: A review and analysis. Int. J. Hydrog. Energy 2009, 34, 8799-8817. [CrossRef]

23. Kraemer, J.T.; Bagley, D.M. Improving the yield from fermentative hydrogen production. Biotechnol. Lett. 2007, 29, 685-695. [CrossRef] [PubMed]

24. Wang, J.; Wan, W. Factors influencing fermentative hydrogen production: A review. Int. J. Hydrog. Energy 2009, 34, 799-811. [CrossRef]

25. Cournac, L.; Sarma, P.M.; Fontecave, M. Biohydrogen: From Basic Concepts to Technology. Int. J. Hydrog. Energy 2010, 35, 10638. [CrossRef]

26. Turner, J.; Sverdrup, G.; Mann, M.K.; Maness, P.C.; Kroposki, B.; Ghirardi, M.; Evans, R.J.; Blake, D. Renewable hydrogen production. Int. J. Energy Res. 2008, 32, 379-407. [CrossRef]

27. Bartacek, J.; Zabranska, J.; Lens, P.N. Developments and constraints in fermentative hydrogen production. Biofuels Bioprod. Biorefining 2007, 1, 201-214. [CrossRef]

28. Nielsen, A.T.; Amandusson, H.; Bjorklund, R.; Dannetun, H.; Ejlertsson, J.; Ekedahl, L.G.; Lundström, I.; Svensson, B.H. Hydrogen production from organic waste. Int. J. Hydrog. Energy 2001, 26, 547-550. [CrossRef]

29. Kim, S.H.; Shin, H.S. Effects of base-pretreatment on continuous enriched culture for hydrogen production from food waste. Int. J. Hydrog. Energy 2008, 33, 5266-5274. [CrossRef]

30. Kim, D.H.; Kim, S.H.; Shin, H.S. Hydrogen fermentation of food waste without inoculum addition. Enzyme Microb. Technol. 2009, 45, 181-187. [CrossRef]

31. Ren, N.; Li, J.; Li, B.; Wang, Y.; Liu, S. Biohydrogen production from molasses by anaerobic fermentation with a pilot-scale bioreactor system. Int. J. Hydrog. Energy 2006, 31, 2147-2157. [CrossRef]

32. Li, J.; Li, B.; Zhu, G.; Ren, N.; Bo, L.; He, J. Hydrogen production from diluted molasses by anaerobic hydrogen producing bacteria in an anaerobic baffled reactor (ABR). Int. J. Hydrog. Energy 2007, 32, 3274-3283. [CrossRef]

33. Yang, P.; Zhang, R.; Mcgarvey, J.; Benemann, J. Biohydrogen production from cheese processing wastewater by anaerobic fermentation using mixed microbial communities. Int. J. Hydrog. Energy 2007, 32, 4761-4771. [CrossRef] 
34. Azbar, N.; Çetinkaya Dokgöz, F.T.; Keskin, T.; Korkmaz, K.S.; Syed, H.M. Continuous fermentative hydrogen production from cheese whey wastewater under thermophilic anaerobic conditions. Int. J. Hydrog. Energy 2009, 34, 7441-7447. [CrossRef]

35. Lay, J.J. Modeling and optimization of anaerobic digested sludge converting starch to hydrogen. Biotechnol. Bioeng. 2000, 63, 269-278. [CrossRef]

36. Ueno, Y.; Haruta, S.; Ishii, M.; Igarashi, Y. Microbial community in anaerobic hydrogen-producing microflora enriched from sludge compost. Appl. Microbiol. Biotechnol. 2001, 57, 555-562. [PubMed]

37. Lin, C.Y.; Cheng, C.H. Fermentative hydrogen production from xylose using anaerobic mixed microflora. Int. J. Hydrog. Energy 2006, 31, 832-840. [CrossRef]

38. Hussy, I.; Hawkes, F.R.; Dinsdale, R.; Hawkes, D.L. Continuous fermentative hydrogen production from sucrose and sugarbeet. Int. J. Hydrog. Energy 2005, 30, 471-483. [CrossRef]

39. Wang, C.H.; Lin, P.J.; Chang, J.S. Fermentative conversion of sucrose and pineapple waste into hydrogen gas in phosphate-buffered culture seeded with municipal sewage sludge. Process Biochem. 2006, 41, 1353-1358. [CrossRef]

40. Fan, K.S.; Kan, N.R.; Lay, J.J. Effect of hydraulic retention time on anaerobic hydrogenesis in CSTR. Bioresour. Technol. 2006, 97, 84-89. [CrossRef] [PubMed]

41. Hawkes, F.R.; Dinsdale, R.; Hawkes, D.L.; Hussy, I. Sustainable fermentative hydrogen production: Challenges for process optimisation. Int. J. Hydrog. Energy 2002, 27, 1339-1347. [CrossRef]

42. Hawkes, F.R.; Hussy, I.; Kyazze, G.; Dinsdale, R.; Hawkes, D.L. Continuous dark fermentative hydrogen production by mesophilic microflora: Principles and progress. Int. J. Hydrog. Energy 2007, 32, 172-184. [CrossRef]

43. Varanasi, J.L.; Roy, S.; Pandit, S.; Das, D. Improvement of energy recovery from cellobiose by thermophillic dark fermentative hydrogen production followed by microbial fuel cell. Int. J. Hydrog. Energy 2015, 40, 8311-8321. [CrossRef]

44. Angenent, L.T.; Karim, K.; Al-Dahhan, M.H.; Wrenn, B.A.; Domíguez-Espinosa, R. Production of bioenergy and biochemicals from industrial and agricultural wastewater. Trends Biotechnol. 2004, 22, 477-485. [CrossRef] [PubMed]

45. Levin, D. Biohydrogen production: Prospects and limitations to practical application. Int. J. Hydrog. Energy 2004, 29, 173-185. [CrossRef]

46. Dipasquale, L.; D'Ippolito, G.; Fontana, A. Capnophilic lactic fermentation and hydrogen synthesis by Thermotoga neapolitana: An unexpected deviation from the dark fermentation model. Int. J. Hydrog. Energy 2014, 39, 4857-4862. [CrossRef]

47. Pradhan, N.; Dipasquale, L.; D’Ippolito, G.; Panico, A.; Lens, P.N.L.; Esposito, G.; Fontana, A. Hydrogen production by the thermophilic bacterium thermotoga neapolitana. Int. J. Mol. Sci. 2015, 16, 12578-12600. [CrossRef] [PubMed]

48. Basak, N.; Das, D. The prospect of purple non-sulfur (PNS) photosynthetic bacteria for hydrogen production: The present state of the art. World J. Microbiol. Biotechnol. 2007, 23, 31-42. [CrossRef]

49. Redwood, M.D.; Paterson-Beedle, M.; MacAskie, L.E. Integrating dark and light bio-hydrogen production strategies: Towards the hydrogen economy. Rev. Environ. Sci. Biotechnol. 2009, 8, 149-185. [CrossRef]

50. Holladay, J.D.; Hu, J.; King, D.L.; Wang, Y. An overview of hydrogen production technologies. Catal. Today 2009, 139, 244-260. [CrossRef]

51. Kapdan, I.K.; Kargi, F.; Oztekin, R.; Argun, H. Bio-hydrogen production from acid hydrolyzed wheat starch by photo-fermentation using different Rhodobacter sp. Int. J. Hydrog. Energy 2009, 34, 2201-2207. [CrossRef]

52. Keskin, T.; Hallenbeck, P.C. Hydrogen production from sugar industry wastes using single-stage photofermentation. Bioresour. Technol. 2012, 112, 131-136. [CrossRef] [PubMed]

53. Nath, K.; Das, D. Improvement of fermentative hydrogen production: Various approaches. Appl. Microbiol. Biotechnol. 2004, 65, 520-529. [CrossRef] [PubMed]

54. Liu, B.F.; Ren, N.Q.; Xie, G.J.; Ding, J.; Guo, W.Q.; Xing, D.F. Enhanced bio-hydrogen production by the combination of dark- and photo-fermentation in batch culture. Bioresour. Technol. 2010, 101, 5325-5329. [CrossRef] [PubMed]

55. Logan, B.E. Microbial Fuel Cell; Wiley \& Sons, Inc.: Hoboken, NJ, USA, 2008. 
56. Rozendal, R.; Hamelers, H.; Euverink, G.; Metz, S.; Buisman, C. Principle and perspectives of hydrogen production through biocatalyzed electrolysis. Int. J. Hydrog. Energy 2006, 31, 1632-1640. [CrossRef]

57. Manish, S.; Banerjee, R. Comparison of biohydrogen production processes. Int. J. Hydrog. Energy 2008, 33, 279-286. [CrossRef]

58. Cusick, R.D.; Bryan, B.; Parker, D.S.; Merrill, M.D.; Mehanna, M.; Kiely, P.D.; Liu, G.; Logan, B.E. Performance of a pilot-scale continuous flow microbial electrolysis cell fed winery wastewater. Appl. Microbiol. Biotechnol. 2011, 89, 2053-2063. [CrossRef] [PubMed]

59. Kadier, A.; Simayi, Y.; Kalil, M.S.; Abdeshahian, P.; Hamid, A.A. A review of the substrates used in microbial electrolysis cells (MECs) for producing sustainable and clean hydrogen gas. Renew. Energy 2014, 71, 466-472. [CrossRef]

60. Ren, L.; Siegert, M.; Ivanov, I.; Pisciotta, J.M.; Logan, B.E. Treatability studies on different refinery wastewater samples using high-throughput microbial electrolysis cells (MECs). Bioresour. Technol. 2013, 136, 322-328. [CrossRef] [PubMed]

61. Hu, H.; Fan, Y.; Liu, H. Hydrogen production in single-chamber tubular microbial electrolysis cells using non-precious-metal catalysts. Int. J. Hydrog. Energy 2009, 34, 8535-8542. [CrossRef]

62. Lu, L.; Xing, D.; Ren, N.; Logan, B.E. Syntrophic interactions drive the hydrogen production from glucose at low temperature in microbial electrolysis cells. Bioresour. Technol. 2012, 124, 68-76. [CrossRef] [PubMed]

63. Lu, L.; Ren, N.; Xing, D.; Logan, B.E. Hydrogen production with effluent from an ethanol-H2-coproducing fermentation reactor using a single-chamber microbial electrolysis cell. Biosens. Bioelectron. 2009, 24, 3055-3060. [CrossRef] [PubMed]

64. Call, D.; Logan, B.E. Hydrogen production in a single chamber microbial electrolysis cell lacking a membrane. Environ. Sci. Technol. 2008, 42, 3401-3406. [CrossRef] [PubMed]

65. Call, D.F.; Merrill, M.D.; Logan, B.E. High surface area stainless steel brushes as cathodes in microbial electrolysis cells. Environ. Sci. Technol. 2009, 43, 2179-2183. [CrossRef] [PubMed]

66. Selembo, P.A.; Perez, J.M.; Lloyd, W.A.; Logan, B.E. High hydrogen production from glycerol or glucose by electrohydrogenesis using microbial electrolysis cells. Int. J. Hydrog. Energy 2009, 34, 5373-5381. [CrossRef]

67. Wang, X.; Cheng, S.; Feng, Y.; Merrill, M.D.; Saito, T.; Logan, B.E. Use of carbon mesh anodes and the effect of different pretreatment methods on power production in microbial fuel cells. Environ. Sci. Technol. 2009, 43, 6870-6874. [CrossRef] [PubMed]

68. Wagner, R.C.; Regan, J.M.; Oh, S.-E.; Zuo, Y.; Logan, B.E. Hydrogen and methane production from swine wastewater using microbial electrolysis cells. Water Res. 2009, 43, 1480-1488. [CrossRef] [PubMed]

69. Pisciotta, J.M.; Zaybak, Z.; Call, D.F.; Nam, J.Y.; Logan, B.E. Enrichment of microbial electrolysis cell biocathodes from sediment microbial fuel cell bioanodes. Appl. Environ. Microbiol. 2012, 78, 5212-5219. [CrossRef] [PubMed]

70. Xiao, L.; Wen, Z.; Ci, S.; Chen, J.; He, Z. Carbon/iron-based nanorod catalysts for hydrogen production in microbial electrolysis cells. Nano Energy 2012, 1, 751-756. [CrossRef]

71. Guo, K.; Tang, X.; Du, Z.; Li, H. Hydrogen production from acetate in a cathode-on-top single-chamber microbial electrolysis cell with a mipor cathode. Biochem. Eng. J. 2010, 51, 48-52. [CrossRef]

72. Hu, H.; Fan, Y.; Liu, H. Hydrogen production using single-chamber membrane-free microbial electrolysis cells. Water Res. 2008, 42, 4172-4178. [CrossRef] [PubMed]

73. Van Groenestijn, J.W.; Geelhoed, J.S.; Goorissen, H.P.; Meesters, K.P.; Stams, A.J.; Claassen, P.A. Performance and population analysis of a non-sterile trickle bed reactor inoculated with caldicellulosiruptor saccharolyticus, a thermophilic hydrogen producer. Biotechnol. Bioeng. 2009, 102, 1361-1367. [CrossRef] [PubMed]

74. Kleerebezem, R.; van Loosdrecht, M.C. Mixed culture biotechnology for bioenergy production. Curr. Opin. Biotechnol. 2007, 18, 207-212. [CrossRef] [PubMed]

75. Kengen, S.W.M.; Goorissen, H.P.; Verhaart, M.; Stams, A.J.M.; van Niel, E.W.J.; Claassen, P.A.M. Biological Hydrogen Production by Anaerobic Microorganisms. In Biofuels; John Wiley \& Sons, Ltd.: Chichester, UK, 2009; pp. 197-221.

76. Kotsopoulos, T.A.; Zeng, R.J.; Angelidaki, I. Biohydrogen production in granular up-flow anaerobic sludge blanket (UASB) reactors with mixed cultures under hyper-thermophilic temperature (70 C). Biotechnol. Bioeng. 2006, 94, 296-302. [CrossRef] [PubMed] 
77. De Vrije, T.; Bakker, R.R.; Budde, M.A.; Lai, M.H.; Mars, A.E.; Claassen, P.A. Efficient hydrogen production from the lignocellulosic energy crop Miscanthus by the extreme thermophilic bacteria Caldicellulosiruptor saccharolyticus and Thermotoga neapolitana. Biotechnol. Biofuels 2009, 2, 12. [CrossRef] [PubMed]

78. Van Niel, E.W.; Budde, M.A.; De Haas, G.; Van der Wal, F.J.; Claassen, P.A.; Stams, A.J. Distinctive properties of high hydrogen producing extreme thermophiles, Caldicellulosiruptor saccharolyticus and Thermotoga elfii. Int. J. Hydrog. Energy 2002, 27, 1391-1398. [CrossRef]

79. Thauer, R.K.; Jungermann, K.; Decker, K. Energy conservation in chemotrophic anaerobic bacteria. Bacteriol. Rev. 1977, 41, 100-180. [PubMed]

80. Vanginkel, S.; Oh, S.; Logan, B. Biohydrogen gas production from food processing and domestic wastewaters. Int. J. Hydrog. Energy 2005, 30, 1535-1542. [CrossRef]

81. Liu, D.; Liu, D.; Zeng, R.J.; Angelidaki, I. Hydrogen and methane production from household solid waste in the two-stage fermentation process. Water Res. 2006, 40, 2230-2236. [CrossRef] [PubMed]

82. Oh, S.-E.; van Ginkel, S.; Logan, B.E. The relative effectiveness of $\mathrm{pH}$ control and heat treatment for enhancing biohydrogen gas production. Environ. Sci. Technol. 2003, 37, 5186-5190. [CrossRef] [PubMed]

83. Liang, T.M.; Cheng, S.S.; Wu, K.L. Behavioral study on hydrogen fermentation reactor installed with silicone rubber membrane. Int. J. Hydrog. Energy 2002, 27, 1157-1165. [CrossRef]

84. Van Groenestijn, J.W.; Hazewinkel, J.H.; Nienoord, M.; Bussmann, P.J. Energy aspects of biological hydrogen production in high rate bioreactors operated in the thermophilic temperature range. Int. J. Hydrog. Energy 2002, 27, 1141-1147. [CrossRef]

85. Kim, D.H.; Han, S.K.; Kim, S.H.; Shin, H.S. Effect of gas sparging on continuous fermentative hydrogen production. Int. J. Hydrog. Energy 2006, 31, 2158-2169. [CrossRef]

86. Koku, H. Aspects of the metabolism of hydrogen production by Rhodobacter sphaeroides. Int. J. Hydrog. Energy 2002, 27, 1315-1329. [CrossRef]

87. Beckers, L.; Masset, J.; Hamilton, C.; Delvigne, F.; Toye, D.; Crine, M.; Thonart, P.; Hiligsmann, S. Investigation of the links between mass transfer conditions, dissolved hydrogen concentration and biohydrogen production by the pure strain Clostridium butyricum CWBI1009. Biochem. Eng. J. 2015, 98, 18-28. [CrossRef]

88. Mizuno, O.; Dinsdale, R.; Hawkes, F.R.; Hawkes, D.L.; Noike, T. Enhancement of hydrogen production from glucose by nitrogen gas sparging. Bioresour. Technol. 2000, 73, 59-65. [CrossRef]

89. Chou, C.; Wang, C.; Huang, C.; Lay, J. Pilot study of the influence of stirring and pH on anaerobes converting high-solid organic wastes to hydrogen. Int. J. Hydrog. Energy 2008, 33, 1550-1558. [CrossRef]

90. Fontes Lima, D.M.; Zaiat, M. The influence of the degree of back-mixing on hydrogen production in an anaerobic fixed-bed reactor. Int. J. Hydrog. Energy 2012, 37, 9630-9635. [CrossRef]

91. Montiel-Corona, V.; Revah, S.; Morales, M. Hydrogen production by an enriched photoheterotrophic culture using dark fermentation effluent as substrate: Effect of flushing method, bicarbonate addition, and outdoor-indoor conditions. Int. J. Hydrog. Energy 2015, 40, 9096-9105. [CrossRef]

92. Clark, I.C.; Zhang, R.H.; Upadhyaya, S.K. The effect of low pressure and mixing on biological hydrogen production via anaerobic fermentation. Int. J. Hydrog. Energy 2012, 37, 11504-11513. [CrossRef]

93. Kim, D.-H.; Shin, H.-S.; Kim, S.-H. Enhanced $\mathrm{H}_{2}$ fermentation of organic waste by $\mathrm{CO}_{2}$ sparging. Int. J. Hydrog. Energy 2012, 37, 15563-15568. [CrossRef]

94. Gómez, X.; Morán, A.; Cuetos, M.J.; Sánchez, M.E. The production of hydrogen by dark fermentation of municipal solid wastes and slaughterhouse waste: A two-phase process. J. Power Sources 2006, 157, 727-732. [CrossRef]

95. Clauwaert, P.; Verstraete, W. Methanogenesis in membraneless microbial electrolysis cells. Appl. Microbiol. Biotechnol. 2009, 82, 829-836. [CrossRef] [PubMed]

96. Cheng, S.; Xing, D.; Call, D.F.; Logan, B.E. Direct biological conversion of electrical current into methane by electromethanogenesis. Environ. Sci. Technol. 2009, 43, 3953-3958. [CrossRef] [PubMed]

97. Pant, D.; van Bogaert, G.; de Smet, M.; Diels, L.; Vanbroekhoven, K. Use of novel permeable membrane and air cathodes in acetate microbial fuel cells. Electrochimica Acta 2010, 55, 7710-7716. [CrossRef]

98. Selembo, P.A.; Merrill, M.D.; Logan, B.E. The use of stainless steel and nickel alloys as low-cost cathodes in microbial electrolysis cells. J. Power Sour. 2009, 190, 271-278. [CrossRef]

99. Maeda, T.; Sanchez-Torres, V.; Wood, T.K. Metabolic engineering to enhance bacterial hydrogen production. Microb. Biotechnol. 2008, 1, 30-39. [CrossRef] [PubMed] 
100. Morimoto, K.; Kimura, T.; Sakka, K.; Ohmiya, K. Overexpression of a hydrogenase gene in Clostridium paraputrificum to enhance hydrogen gas production. FEMS Microbiol. Lett. 2005, 246, 229-234. [CrossRef] [PubMed]

101. Vardar-Schara, G.; Maeda, T.; Wood, T.K. Metabolically engineered bacteria for producing hydrogen via fermentation. Microb. Biotechnol. 2008, 1, 107-125. [CrossRef] [PubMed]

102. Hallenbeck, P.C.; Ghosh, D. Improvements in fermentative biological hydrogen production through metabolic engineering. J. Environ. Manag. 2012, 95, S360-S364. [CrossRef] [PubMed]

103. Ryu, M.-H.; Hull, N.C.; Gomelsky, M. Metabolic engineering of Rhodobacter sphaeroides for improved hydrogen production. Int. J. Hydrog. Energy 2014, 39, 6384-6390. [CrossRef]

104. Wang, J.; Wan, W. Kinetic models for fermentative hydrogen production: A review. Int. J. Hydrog. Energy 2009, 34, 3313-3323. [CrossRef]

105. Dincer, I. Hydrogen and Fuel Cell Technologies for Sustainable Future. Jordan J. Mech. Ind. Eng. 2008, 2, $1-14$.

106. Rathore, D.; Singh, A. Biohydrogen production from microalgae. In Biofuels Technologies Recent Developments; Gupta, V., Tuohy, M., Eds.; Springer: Berlin/Heidelberg, Germany, 2013; pp. 317-333.

107. Kwak, H.Y.; Lee, H.S.; Jung, J.Y.; Jeon, J.S.; Park, D.R. Exergetic and thermoeconomic analysis of a 200-kW phosphoric acid fuel cell plant. Fuel 2004, 83, 2087-2094. [CrossRef]

108. Rubio Rodríguez, M.A.; de Ruyck, J.; Díaz, P.R.; Verma, V.K.; Bram, S. An LCA based indicator for evaluation of alternative energy routes. Appl. Energy 2011, 88, 630-635. [CrossRef]

109. Romagnoli, F.; Blumberga, D.; Pilicka, I. Life cycle assessment of biohydrogen production in photosynthetic processes. Int. J. Hydrog. Energy 2011, 36, 7866-7871. [CrossRef]

110. Djomo, S.N.; Humbert, S. Dagnija Blumberga Life cycle assessment of hydrogen produced from potato steam peels. Int. J. Hydrog. Energy 2008, 33, 3067-3072. [CrossRef]

111. Djomo, S.N.; Blumberga, D. Comparative life cycle assessment of three biohydrogen pathways. Bioresour. Technol. 2011, 102, 2684-2694. [CrossRef] [PubMed]

112. Ochs, D.; Wukovits, W.; Ahrer, W. Life cycle inventory analysis of biological hydrogen production by thermophilic and photo fermentation of potato steam peels (PSP). J. Clean. Prod. 2010, 18, S88-S94. [CrossRef]

113. Chen, S.D.; Lo, Y.C.; Lee, K.S.; Huang, T.I.; Chang, J.S. Sequencing batch reactor enhances bacterial hydrolysis of starch promoting continuous bio-hydrogen production from starch feedstock. Int. J. Hydrog. Energy 2009, 34, 8549-8557. [CrossRef]

114. Seifert, K.; Waligorska, M.; Wojtowski, M.; Laniecki, M. Hydrogen generation from glycerol in batch fermentation process. Int. J. Hydrog. Energy 2009, 34, 3671-3678. [CrossRef]

115. Lin, C.N.; Wu, S.Y.; Chang, J.S.; Chang, J.S. Biohydrogen production in a three-phase fluidized bed bioreactor using sewage sludge immobilized by ethylene-vinyl acetate copolymer. Bioresour. Technol. 2009, 100, 3298-3301. [CrossRef] [PubMed]

116. Yasin Nazlina, H.M.; Aini, R.; Ismail, F.; Zulkhairi, M.; Hassan, M.A. Effect of different temperature, initial $\mathrm{pH}$ and substrate composition on biohydrogen production from food waste in batch fermentation. Asian J. Biotechnol. 2009, 1, 42-50.

117. Zhu, J.; Li, Y.; Wu, X.; Miller, C.; Chen, P.; Ruan, R. Swine manure fermentation for hydrogen production. Bioresour. Technol. 2009, 100, 5472-5477. [CrossRef] [PubMed]

118. Gadhamshetty, V.; Johnson, D.C.; Nirmalakhandan, N.; Smith, G.B.; Deng, S. Feasibility of biohydrogen production at low temperatures in unbuffered reactors. Int. J. Hydrog. Energy 2009, 34, 1233-1243. [CrossRef]

119. Ghosh, D.; Hallenbeck, P.C. Fermentative hydrogen yields from different sugars by batch cultures of metabolically engineered Escherichia coli DJT135. Int. J. Hydrog. Energy 2009, 34, 7979-7982. [CrossRef]

120. Kargi, F.; Pamukoglu, M.Y. Dark fermentation of ground wheat starch for bio-hydrogen production by fed-batch operation. Int. J. Hydrog. Energy 2009, 34, 2940-2946. [CrossRef]

121. Han, W.; Ye, M.; Zhu, A.J.; Zhao, H.T.; Li, Y.F. Batch dark fermentation from enzymatic hydrolyzed food waste for hydrogen production. Bioresour. Technol. 2015, 191, 24-29. [CrossRef] [PubMed]

122. Chookaew, T.; O-Thong, S.; Prasertsan, P. Biohydrogen production from crude glycerol by two stage of dark and photo fermentation. Int. J. Hydrog. Energy 2015, 40, 7433-7438. [CrossRef] 
123. Wicher, E.; Seifert, K.; Zagrodnik, R.; Pietrzyk, B.; Laniecki, M. Hydrogen gas production from distillery wastewater by dark fermentation. Int. J. Hydrog. Energy 2013, 38, 7767-7773. [CrossRef]

124. Moreno, R.; Escapa, A.; Cara, J.; Carracedo, B.; Gómez, X. A two-stage process for hydrogen production from cheese whey: Integration of dark fermentation and biocatalyzed electrolysis. Int. J. Hydrog. Energy 2015, 40, 168-175. [CrossRef]

125. Su, H.; Cheng, J.; Zhou, J.; Song, W.; Cen, K. Hydrogen production from water hyacinth through dark- and photo- fermentation. Int. J. Hydrog. Energy 2010, 35, 8929-8937. [CrossRef]

126. Argun, H.; Kargi, F. Effects of sludge pre-treatment method on bio-hydrogen production by dark fermentation of waste ground wheat. Int. J. Hydrog. Energy 2009, 34, 8543-8548. [CrossRef]

127. Laurinavichene, T.V.; Belokopytov, B.F.; Laurinavichius, K.S.; Tekucheva, D.N.; Seibert, M.; Tsygankov, A.A. Towards the integration of dark- and photo-fermentative waste treatment. 3. Potato as substrate for sequential dark fermentation and light-driven $\mathrm{H}_{2}$ production. Int. J. Hydrog. Energy 2010, 35, 8536-8543. [CrossRef]

128. Ozmihci, S.; Kargi, F. Effects of starch loading rate on performance of combined fed-batch fermentation of ground wheat for bio-hydrogen production. Int. J. Hydrog. Energy 2010, 35, 1106-1111. [CrossRef]

129. Avcioglu, S.G.; Ozgur, E.; Eroglu, I.; Yucel, M.; Gunduz, U. Biohydrogen production in an outdoor panel photobioreactor on dark fermentation effluent of molasses. Int. J. Hydrog. Energy 2011, 36, 11360-11368. [CrossRef]

130. Zhu, Z.; Shi, J.; Zhou, Z.; Hu, F.; Bao, J. Photo-fermentation of Rhodobacter sphaeroides for hydrogen production using lignocellulose-derived organic acids. Process Biochem. 2010, 45, 1894-1898. [CrossRef]

131. Francou, N.; Vignais, P.M. Hydrogen production by Rhodopseudomonas capsulata cells entrapped in carrageenan beads. Biotechnol. Lett. 1984, 6, 639-644. [CrossRef]

132. Taguchi, F.; Mizukami, N.; Hasegawa, K.; Saito-Taki, T. Microbial conversion of arabinose and xylose to hydrogen by a newly isolated clostridium sp. No. 2. Can. J. Microbiol. 1994, 40, 228-233. [CrossRef]

133. Susanti, R.F.; Dianningrum, L.W.; Yum, T.; Kim, Y.; Lee, B.G.; Kim, J. High-yield hydrogen production from glucose by supercritical water gasification without added catalyst. Int. J. Hydrog. Energy 2012, 37, 11677-11690. [CrossRef]

134. Qinming, Z.; Shuzhong, W.; Liang, W.; Donghai, X. Catalytic Hydrogen Production from Municipal Sludge in Supercritical Water with Partial Oxidation. Chall. Power Eng. Environ. 2007, 1, 1252-1255.

135. Frusteri, F.; Freni, S.; Chiodo, V.; Spadaro, L.; Bonura, G.; Cavallaro, S. Potassium improved stability of $\mathrm{Ni} / \mathrm{MgO}$ in the steam reforming of ethanol for the production of hydrogen for MCFC. J. Power Sour. 2004, 132, 139-144. [CrossRef]

136. Aiello, R.; Fiscus, J.E.; Loye, H.; Amiridis, M.D. Hydrogen production via the direct cracking of methane over $\mathrm{Ni} / \mathrm{SiO}_{2}$ : Catalyst deactivation and regeneration. Appl. Catal. A Gen. 2000, 192, 227-234. [CrossRef]

137. Deng, W.; Jiang, H.; Wu, Y.; Fan, H.; Ji, J. Hydrogen production from biomass pyrolysis in molten alkali. AASRI Procedia 2012, 3, 217-223.

138. Sivasubramanian, P.; Ramasamy, R.P.; Freire, F.J.; Holland, C.E.; Weidner, J.W. Electrochemical hydrogen production from thermochemical cycles using a proton exchange membrane electrolyzer. Int. J. Hydrog. Energy 2007, 32, 463-468. [CrossRef]

139. Kim, J.; Kwon, D.; Kim, K.; Hoffmann, M.R. Electrochemical Production of Hydrogen Coupled with the Oxidation of Arsenite. Environ. Sci. Technol. 2014, 48, 2059-2066. [CrossRef] [PubMed]

140. Karn, R.K.; Srivastava, O.N. On the synthesis and photochemical studies of nanostructured TiO 1 and TiO 1 admixed VO 1 photoelectrodes in regard to hydrogen production through photoelectrolysis. Int. J. Hydrog. Energy 1999, 24, 965-971. [CrossRef]

141. Perlack, R.D.; Wright, L.L.; Turhollow, A.F.; Graham, R.L.; Stokes, B.J.; Erbach, D.C. Biomass as Feedstock For a Bioenergy and Bioproducts Industry: The Technical Feasibility of a Billion-Ton Annual Supply; U.S. Department of Energy: Oak Ridge, TN, USA, 2005.

(C) 2015 by the authors; licensee MDPI, Basel, Switzerland. This article is an open access article distributed under the terms and conditions of the Creative Commons by Attribution (CC-BY) license (http://creativecommons.org/licenses/by/4.0/). 